\title{
Ignacio Ellacuría: Un pensamiento y una opción
}

\author{
Mauricio Viquez Lizano*
}

Recibido: Julio 2011 • Aceptado: Setiembre 2011

\section{RESUMEN}

El ensayo busca una aproximación al pensamiento y opción de Ignacio Ellacuría, teológo jesuita, asesinado en 1989, en el campus de la Universidad Centroamericana de El Salvador. Entre otros conceptos analizados por el autor están: La noción de "pobre" como lugar teológico y la "civilización de la pobreza" como propuesta profética y utópica. Para estudiar estos conceptos centrales en la obra de Ellacuría, el autor examina categorías como: Realidad histórica, materialidad, círculo hermenéutico, teología de la liberación, utopía y profetismo, y mysterium liberationis. Con base en la obra estudiada termina el análisis reconociendo como alternativa única la necesidad de globalizar la solidaridad.

Palabras clave: Realidad histórica. Pobre. Civilización de la pobreza. Profetismo y utopía. Praxis eclesial. Teología histórica. Globalización de la solidaridad.

\section{ABSTRACT}

This essay seeks an approximation to the thought and option of Ignacio Ellacuría, a Jesuit theologian, killed in 1989 in the campus of the Universidad Centroamericana of El Salvador. Among other concepts analyzed by the author there are: The notion of "poor" as a theological place and the "civilization of the poverty" as a prophetic and utopian proposal. To study these central concepts in the work of Ellacuría, the author examines categories such as: Historic reality, materiality, hermeneutic circle, theology of the freedom, utopia and prophecy, and mysterium liberationis. Based on the studied work, he finishes the analysis by recognizing the necessity of globalizing the solidarity as a unique alternative.

Key words: Historic reality, Poor, Civilization of the poverty, Utopia and prophecy, Church praxis, Historic theology, Globalizing the solidarity.

* Magister en Teología Moral Social énfasis en Doctrina Social de la Iglesia y Desarrollo Humano por Univ. Juan Pablo II. Doctor en Estudios Latinoamericanos, UNA y Doctor en filosofía por la Atlantic International University de Florida. Coordinador de la maestría en teología católica de UNED, y profesor en UCR, Universidad Católica de CR, Universidad Latina de CR y en la Universidad Juan Pablo II. Varias publicaciones de artículos y libros, columnista dominical de La Nación y Eco Católico. Mail: canino@racsa.co.cr 


\section{Introducción}

Me propongo mediante estas líneas hacer una aproximación al pensamiento de un hombre que, dentro de su personalidad cristiana sin dobleces y su talante socrático, logró mirar más allá aunque, obviamente, desde las alturas a las que le permitieron ascender sus grandes maestros.

Arribar a encarnar su perspectiva teológica en el marco de la historia y a ella, en cuanto comprendida como actualización de posibilidades, le llevó toda su vida. Pudo ir más allá, pero las circunstancias lo hicieron detenerse en una tremenda noche de noviembre de 1989 en el campus de la Universidad Centroamericana de El Salvador.

En esa visión tan particular, Ellacuría mira los temas que aquí abordaremos. Buscamos, desde la génesis de un pensamiento, acercarnos a la noción de "pobre" en cuanto lugar teológico y a la categoría de "civilización de la pobre$\mathrm{za}$ " en cuanto propuesta profética y utópica propia de la etapa última de su pensamiento.

\section{Líneas generales del pensamiento filosófico inicial de Ellacuría}

En los primeros años de fomación de Ignacio Ellacuría (+1989), su gran empeño fue buscar pistas hacia una filosofía más vital, capaz de afrontar temas urgentes. Trata de sintetizar lo escolástico con el raciovitalismo de Ortega.

La influencia de Aurelio Espinosa y Ángel Martínez -sus primeros maestros-será muy importante. Del primero toma el interés por el ser humano y los problemas que le aquejan, sabiendo que, para ello, es fundamental entrar en contacto con lo más concreto de la vida de las personas. Es el tiempo del contacto inicial de Ellacuría con las corrientes existencialistas y vitalistas en boga en ese momento.

De Martínez la influencia es igual o más decisiva. De él asume un fuerte espíritu crítico de cara a la realidad occidental y, en ella, la capacidad de descubrirle los elementos menos agraciados para buscar su transformación. La filosofía se ha de proponer partir de la realidad y ayudar al ser humano a reconciliar su existencia vital con su esencia verdadera. La poética de Martínez le conduce a la síntesis de elementos, sobre todo, elementos de tipo intemporal-modernos, así como la síntesis entre riqueza metafísica y la profundidad humana.

Se ha de ir, pues, más allá de la filosofía que sólo es ejercicio intelectual ajeno a la vida del filósofo. No puede haber disociación entre el sistema del filósofo y la propia vida. "Para Ellacuría, en cambio, 
el sentido pleno de la función intelectual sólo se alcanza cuando se orienta hacia la vida" (Samour, 1999). Se trata, en fin, de estar abiertos al ser para enriquecer la existencia humana. Llegará el momento en que Ellacuría escribirá al respecto diciendo que la misión de la filosofía no puede ser otra sino "despertar el alma de los hombres" (Samour, 2000) para que pueda llegar a una vida verdadera.

Poco a poco, Ellacuría andará en la búsqueda de pistas para una reflexión más integradora. Ya había descubierto las posibilidades del tomismo para la promoción de un verdadero humanismo. Tomás se le aparecía como el modelo del intelectual católico, libre de prejuicios y abierto a lo nuevo, capaz de la mayor de las síntesis entre fe y razón, ubicado de frente a su opción continua, esto es, la verdad. Pronto notará otro elemento: la necesidad de encontrar una propuesta más capaz de decir algo al ser humano, más vital que lo que podía hacer la neoscolástica vigente y que para nada era desconocida para nuestro autor (Valdés, 1996).

Surge así una nueva urgencia: poner en diálogo sus posiciones de entonces con las de Ortega y su vitalismo, un interés que venía ya desde antes de su llegada a formarse en Austria y que no dejaba de resultar peculiar tomando en cuenta el mal concepto que de este autor se tenía en círculos eclesiásticos, sobre todo, españoles. Llama la atención a Ellacuría el sentido vital y humano de la reflexión orteguiana, a pesar de que Ortega miraba la vida como fin de sí misma. A pesar de algunos "peros", Ellacuría llega a valorar "positivamente la fenomenología orteguiana como método de acceso para captar la realidad humana a partir de lo que los seres humanos concretos manifiestan en las situaciones cotidianas en las que están inmersos" (Samour, 2000). La finalidad de la propuesta de Ortega nunca fue-como en el caso de Heidegger-construir una ontología general, sino mostrar al ser humano en cuanto histórico, en perspectiva, haciéndose, de cara a posibilidades y a un entorno o circunstancia que le invita a las decisiones (Chavez, 1998: 208ss). El panorama de este pensamiento resultaba muy atrayente para Ellacuría.

Luego de 1963, piensa Ellacuría en dar un paso más. Aunque le era conocido desde 1962, es un poco más adelante cuando encuentra la guía que buscaba y que se añadía a todo cuanto había podido descubrir en su etapa de Insbruck a la par de Rahne. Así llega a X. Zubiri con quien y sobre quien trabajaría su tesis doctoral en filosofía. Se encuentra con algo más que un esfuerzo por conciliar lo perenne y lo moderno. Se ubica ante una filosofía trans-escolástica que va más 
allá del existencialismo. Ellacuría mismo dirá que en Zubiri encontró una "muestra espléndida de un filosofar vital, auténtico" (Ellacuría, 1996, 403). Un pensamiento que le abre posibilidades, le lleva a asombrarse de cuánto el filosofar puede ser un estilo de vida y la perspectiva historizada de un ser humano que "acontece".

Zubiri será un paso esencial. Pero no sólo para repetirlo. Habrá que utilizarlo de cara a resolver problemas que él mismo nunca tuvo ocasión de conocer.

Para 1966, se inicia el camino de Ellacuría rumbo a planteamientos nuevos. El impacto de las nuevas corrientes filosófico-teológicas europeas, la experiencia revolucionaria en América Latina, y la celebración de la conferencia en Medellín, determinan un horizonte de intereses nuevos en nuestro autor. Sin dejar su interesante trabajo al lado de Zubiri, su esfuerzo se dirige a temas nuevos, más teológicos que filosóficos y en una óptica liberadora.

Llegamos así a su obra Filosofía de la realidad histórica. Aparece en 1990 -de modo póstumo-y, en este libro, Ellacuría presenta la realidad histórica como aquel grado de realidad que comprende a los demás: lo físico, lo orgánico, los animales y la realidad humana en sus niveles personal, psicológico, familiar, grupal, social y político-económico.
Nada le es ajeno a su enfoque. Se fija en la historia y su pasión está en comprenderla y en influirla ${ }^{1}$.

\section{La perspectiva zubiriana como factor determinante}

La actitud de Ignacio Ellacuría como intelectual se caracterizó desde sus años de seminario por una valoración y realización de diálogo para sacar provecho de quienes le han precedido en el enfrentamiento de la intelección de las cosas. Hace su propia cosecha de Zubiri, sobre todo en el apartarse del idealismo y replantearse el quehacer intelectual sosteniendo que la filosofía debe tender a la efectividad. Se trata de la idea de la situacionalidad de la inteligencia. En diálogo con los principales filósofos de los horizontes tradicionales de la filosofía y en actitud de prolongación de la obra de Zubiri, aprecia y retoma los aportes como por ejemplo del marxismo, de todo aquello que sirva a la causa de dar prioridad al mero hacer avanzar el conocimiento. Analizar la realidad consiste en un saber acerca de las cosas, saber sobre la dirección política del mundo, en la filosofía como forma de vida. El mundo, la razón y la vida

\footnotetext{
1. De gran interés el artículo de J. Sols, El legado de Ignacio Ellacuría, Cuadernos Cristianismo i Justicia, ubicable en www.fespinal.com
} 
obligan a la filosofía a ser histórica y política para lograr crecimiento de libertad como liberación.

Este fue el perfil intelectual de Ellacuría, una personalidad compleja que parte de lo real y actualiza la realidad en su inteligencia para actuar en un horizonte de liberación desde una praxis liberadora y desde una motivación de fe cristiana. Su enfoque del quehacer intelectual replantea el hecho del saber de las cosas: analizar y actuar sobre la realidad manteniendo un horizonte utópico- al que se quiere llegar, evaluar desde ese horizonte lo logrado sin caer en la aceptación resignada y des-responsabilizada de lo que se puede y no se puede hacer.

El quehacer intelectual debe ser radical, yendo a las raíces de los problemas. Jon Sobrino señala tres dimensiones analíticas que caracterizaron a Ellacuría en su labor intelectual: “(...) en el quehacer intelectual de Ellacuría se pueden apreciar claramente tres dimensiones analíticas: la dimensión presocrática queda de alguna forma expresada en la inmediatez con que se enfrentó a la realidad, sobre todo a la realidad sufriente de los pueblos crucificados y en la apertura a cambiar y buscar nuevas categorías conceptuales, sin presuponer que siempre tenía de antemano categorías adecuadas para abordar la novedad de los procesos. La dimensión aristotélica, analítica, la expresan sus análisis teóricos de todo tipo: teológicos, filosóficos (...) y su instrumental rahneriano, zubiriano, marxiano, por los que es más conocido por lo de lejos. La dimensión socrática, por último, queda expresada en la voluntad de transformar la realidad, cargando con ella, sin rehuir la consecuencias del enfrentamiento directo con los poderes del mundo: como Sócrates, ser acusado de corromper a los ciudadanos y de ateísmo, y ser por ello ajusticiado."2

En su quehacer intelectual Ellacuría tiene presente la realidad porque ella se expresa en todos los lugares y no del mismo modo. "La verdad de la realidad no es lo ya hecho; eso es sólo una parte de la realidad. Si no nos volvemos a lo que está haciéndose y a lo que está por hacer, se nos escapa la verdad de la realidad. Hay que hacer la verdad, lo cual no supone, primariamente, poner en ejecución, realizar lo que ya se sabe; sino hacer aquella realidad, que en juego de praxis y teoría se muestra como verdadera, (...) la realidad y la verdad han de hacerse y descubrirse (...) han de hacerse y descubrirse en la complejidad colectiva y sucesiva de la historia de la humanidad" (Ellacuría, 1999: 599).

\footnotetext{
2. Así anotado por este autor en un artículo que apareciera en su momento en la Revista Latinoamericana de Teología, (1994) 33, p. $30-31$.
} 
Refiriéndose a este quehacer, Ignacio Ellacuría explica que, a lo largo de la filosofía, se han visto las cosas o sólo como experiencia biográfica o sólo como experiencia histórica. Una u otra forma de ver las cosas ha sido, hasta hace poco, cómo se ha conceptualizado la realidad. Y precisamente es aquí en donde se encuentra lo más grave del problema: que se ha partido de esta conceptualización para regresar a la realidad y enfrentarla. Es decir, no se ha resuelto el problema, sino que se ha ideologizado, lo cual significa que se está encubriendo y deformando la realidad. Encima de todo se está desconociendo la realidad por no conceptualizarla adecuadamente. Este es el punto medular que tiene insatisfecho a Ellacuría y ve la posibilidad de señalar las imprecisiones de algunas corrientes de la filosofía de la historia: “... no puede tratarse -citan a Ellacuría los autores Scannone y Trigo (1999:22) - de la naturaleza sin referirse a la historia, ni del hombre sin referirse a la sociedad y, recíprocamente, no puede hablarse de la historia sin referirse a la naturaleza, de la sociedad sin referirse al hombre". En cada uno de los tres grandes filósofos -Hegel, Marx y Zubiri- Ellacuría ve la oportunidad de un diálogo, pero en clave de ir más allá, tratando de sacar hasta las últimas conclusiones, viendo en cada uno cómo planteaban el objeto de la filosofía. Su aporte, pues, y toda la pretensión sistemática de su filosofía, señala sus pretensiones de ir más allá del realismo ingenuo y el idealismo, más allá del racio-vitalismo de Ortega, más allá, inclusive, de la filosofía teologal de Zubiri para postularla como objeto de la Filosofía; aportar que la realidad histórica es el lugar privilegiado de la ética, exigencia básica de la política y de la economía.

El quehacer intelectual de Ellacuría tiene -como ha quedado dicho- su máxima expresión en su obra Filosofía de la Realidad Histórica, un análisis de las distintas estructuras y los dinamismos que componen la realidad histórica, considerada en su totalidad y en su plena concreción, con el objetivo principal de iluminar los supuestos requeridos para que se pueda dar, real y plenamente, una praxis histórica de liberación. Como es una obra inconclusa debido a su asesinato puede pensarse que no existe una elaboración sistemática en su filosofía. Pero esto cambia si se analiza que con su publicación nos enfrentamos a un corpus filosófico coherente y original. La edición estuvo a cargo de Antonio González Fernández, sobre la base de un texto mecanografiado que Ellacuría le había confiado en 1985, y al cual añadió como introducción y como conclusión el texto sobre "El Objeto de la Filosofía" que Ellacuría 
había publicado en la revista Estudios Centroamericanos en 1981. El texto original lo había redactado ya desde 1976. Es la labor máxima de la filosofía de Ellacuría.

Es en esta obra donde Ellacuría asume y utiliza positivamente las tesis epistemológicas, antropológicas y metafísicas de la filosofía zubiriana ${ }^{3}$.

\section{Filosofía de la realidad histórica}

Como ya sabemos, Ellacuría busca continuar, aplicar e historizar

3. Mora Galiana nos ayuda a comprender el iter de Ellacuría al sintetizar: "Ignacio Ellacuría, siguiendo las huellas de Zubiri, sobre todo las impresas en Estructura dinámica de la Realidad, concretará su pensamiento filosófico en unos cuadernos que, como material académico, fueron publicados en 1984 en la Universidad Centro Americana (UCA), a los que seguirá un curso sobre el 'sujeto de la Historia', que dará pie, posteriormente, a su obra-proyecto Filosofía de la Realidad Histórica, que gracias al profesor Antonio González podemos ahora estudiar y conocer detenidamente.

En dicha obra, como concluía Zubiri, todos los dinamismos, y el propio devenir de la realidad dinámica, constituyen una unidad interna, y además intrínseca, que es el dinamismo de la realidad en tanto que realidad. Pues tanto los momentos como los ingredientes que constituyen la realidad son activos y dinámicos por sí mismos. En consecuencia, la realidad histórica es objeto de la Filosofía. Pero ese proyecto será ya un proyecto de madurez, una obra autónoma, lamentablemente no concluido" Ubicable en http://ensayo.rom.uga.edu o bien en www. ensayistas.org el pensamiento de Zubiri en un contexto concreto, sabiendo de antemano que, por las características mismas de ese pensamiento, sobre todo por su realismo abierto, no resulta tan ardua la labor de lograr el aterrizaje. Y ello de modo que una filosofía rigurosa como la zubiriana cumpla con el propósito que ha de buscar toda filosofía: hacer de contacto con la realidad, interpretarla y plantear vías de transformación.

Ahora, Ellacuría, al profundizar creativamente a su maestro y al escuchar de modo atento el reclamo de la realidad, supo superar el peligro de sólo repetir. Muy pronto llega a decir que la filosofía está llamada a ocuparse de la realidad total y que esa totalidad se concreta y realiza en la historia y por la historia. "Lo último de la realidad, lo metafísico, no es accesible por el camino de la máxima abstracción, sino por la vuelta a lo que es el máximo de concreción (...) esta total concreción es no sólo procesual $-\mathrm{y}$ en este sentido, evolutiva-, sino formalmente histórica" (Ellacuría, 1993: 50s). Y esa historia es el objeto verdadero de la filosofía. Así lo sostenía al menos hasta 1980, cuando se agrega una precisión: Ellacuría deja de hablar de sólo historia para dar un paso más y comenzar a hablar de realidad histórica al referirse al objeto de la filosofía. Un paso que él mismo considera- 
rá como una radicalización de la metafísica zubiriana ${ }^{4}$.

Antonio González, al referirse a esta obra ellacuriana, por lo demás no concluida, como se ha dicho, luego de contextualizarla dentro de una filosofía latinoamericana en proceso de consolidación, ubica tres tesis fundamentales que vendrían a ser las siguientes ${ }^{5}$ :

- La realidad histórica es entendida como apropiación de posibilidades y no como desarrollo en acto de lo que en potencia está ya dado al principio de la misma. Así, con Zubiri, va más allá de ciertas categorías aristotélicas, para mirar las cosas de modo diverso, incluso para mirar la historia como creación e innovación, posibilidades que se levantan sobre bases materiales, biológicas, sociales y económicas determinadas.

- Así el proceso histórico es más praxis que otra cosa.

4. Sobre este tema es de utilidad el artículo de H. Samour, publicado electrónicamente en el sitio www.ensayo.rom.uga.edu, titulado Historia, praxis y liberación en el pensamiento de Ignacio Ellacuría, que recoge la ponencia de su autor en el Congreso Internacional Xavier Zubiri en julio de 1993.

5. Seguimos aquí su artículo Filosofía de la historia y liberación, Revista Electrónica Latinoamericana de Teología (ReLat) 22, ubicable en www.servicioskoinonia.org
- Es la humanidad el sujeto de la historia. No lo es ningún macrosujeto (la naturaleza o la razón). Y en ese empeño ha de buscar desembocar en una meta ética: una vida planetaria racional y democráticamente correcta.

\section{La realidad histórica, objeto de la filosofía, en cuanto ámbito de actuación humana}

Según Ellacuría, la historia surge de la naturaleza material. Estamos ante la materialidad de la historia.

Al hablar de materialidad se piensa en la materia en cuanto nota última y fundante, por lo que se mira el cosmos como unidad material. La materia es lo constituyente de todo lo intramundano dinámico y, además, capaz de desplegar su poder. Ahora, toda cosa material tiene su espacio en el cosmos, su posición. Y allí cada cosa es respectiva: no se confunde con las demás, pero está vertida. El espacio permite regionalizar y estabilizar la materia.

Ahora, aparte de la espaciocidad de lo real, hay que hablar de la temporalidad de la materia. Esto nos obliga a fijarnos en el tiempo en cuanto que distensión, esto es, se trata de una forma de realidad en que una nota sucede a otra, es un pasar que tiene conexión, dirección y medida. Es esencial tener 
presente, además, que las cosas y el tiempo no resultan realidades separadas, pues las cosas, más que transcurrir en el tiempo, transcurren temporalmente.

Otro elemento. Ellacuría concibe lo social como componente de la historia. Y, en esa sociedad, el centro lo ocupa la especie humana y cada quien con su phylum interiorizado -por tanto único e individual- y, a la vez, abierto. Así es como lo social resulta de una habitud social, esto es, de un modo de habérselas con los otros, para lo cual tiene las suficientes capacidades el individuo.

Surge, así, un convivir que origina un cuerpo social en el que, más que personas, ubicamos seres humanos. Un cuerpo que desarrolla una especie de conciencia que integra y legitima los valores y el acerbo cultural.

Cada miembro de la especie humana, por su pertenencia filética, se asimila a los demás seres humanos, pero al estar vertidos entre ellos y de frente a ellos-debido también al modo de interiozar cada uno el phylum - es diverso. Así nos encontramos con personas referidas a los demás, con quienes se ha de convivir a partir de un esquema YO-TÚ-ÉL-LOS DEMÁS que implica refluencia y codeterminación.

$\mathrm{Y}$ todo enmarcado en el tiempo que el ser humano está llamado a autoposeer, sabiendo que ese proceso no es igual en todos los seres humanos que pueden ser coetáneos pero no siempre contemporáneos. Un proceso que muestra al hombre expuesto a lo que tiene delante, aunque, a la vez, debe proyectarse en su acontecer vital: llamado a vivir el tiempo no sólo como sucesión o duración-memoria, sino como presesión, o sea, de cara al futuro (Ellacuría, 1999: 481).

\section{Historia, entonces ¿qué es?}

La historia no flota sobre sí, tiene su raíz en la naturaleza, es transmisión que tiene sus raíces en el phylum y en el modo humano de transmisión porque ella se da, justamente, en la especie humana que, a su vez, necesita de un modo de estar en la realidad.

Nos ubicamos así ante una transmisión que resulta ser tridente (Ellacuría, 1999: 496) por cuanto implica tres momentos esenciales:

- constituyente: esto es, cómo se instala el viviente en la historia;

- continuante: la forma continuante y a la vez innovadora de estar que es propia del phylum;

- progrediente: desde lo recibido el ser humano se anima a realizarse, se hace cargo de su vida y la lleva adelante.

Así nos ubicamos ante una historia que en nuestro autor es 
actualización de posibilidades o, si se prefiere, "proceso creacional" (Ellacuría, 1999: 562) o un dinamismo de posibilitación que es entrega de realidad, formas de estar en ella en cuanto principio de posibilidades que pasan a ser realidad por opción y a incorporarse por apropiación.

Es, así, la historia un poder que posibilita la opción, que abre la vía hacia la realidad y que se incorpora a la vida de las personas por apropiación (Ellacuría, 1999: 532). De aquí que la historia sea, entonces, el suceso de los modos de estar en la realidad.

Ellacuría deja, además, en claro, que en la historia intervienen fuerzas y dinamismos. Las fuerzas mueven la historia y pueden ser naturales (las capacidades en términos de recursos, por ejemplo, biológicas (implicaciones en realidades como la salud, la enfermedad o la muerte), psíquicas (los talentos de cada quien), sociales (modas, modo de proceder de los grupos de presión organizados), políticas (la acción del estado, ej.) o personales (actos de opción realizados por alguien). Los dinamismos del proceso histórico nos hablan de ese dar siempre de sí que implica el acontecer y que implica realización, esto es, un ir a más.

Ahora, ese ser humano vertido entre las cosas y los otros seres humanos, interviene haciendo. Así llegamos a la praxis que podríamos entender como la "intromisión de la actividad humana, como creación de capacidades y apropiación de posibilidades, en el curso dinámico de la historia" (Ellacuría, 1999: 594). En esta praxis el hombre toma sobre sus hombros el hacerse cargo de la historia y en una ruta civilizatoria ${ }^{6}$ que ha de ser correcto $^{7}$ y acompañada por momentos teóricos que permitan actuar-como dice nuestro autor en sus Escritos políticos- con un grado adecuado de conciencia (Ellacuría, 1993: 119s).

6. Cuando Ignacio Ellacuría habla de civilización piensa en muchas cosas: primero, en un ser humano vertido y enfrentado a lo real con capacidad de crear capacidades y de apropiarse de posibilidades. Ese ser humano al tener la posibilidad de poder optar, lo hace. Y el producto de la acción de la especie humana -esto es, todos los que comparten el phylum humano común- hace resultar la civilización.

7. Un concepto del útimo Ellacuría decisivo será el de civilización de la pobreza, que consiste no en promover la pauperización general, sino en promover un dinamismo diferente que supera la lógica que lleva a absolutizar el binomio capital-riqueza. Busca enfrentar la centralidad de la acumulación desde una nueva concepción del trabajo como vía de perfeccionamiento y no como actividad promotora de explotación y de profundización de brechas entre los que tienen y los que no. Estamos ante una concepción de la vida que además resulta ser altamente solidaria y con un uso de cuanto se posee con una dimensión social muy en coherencia con la enseñanza social de la Iglesia planteada así desde el inicio de sus formulaciones en 1891 . 


\section{De la "historización de la inteligencia" a la teología histórica}

En nuestro autor la "realidad histórica" es "objeto último" de la Filosofía, entendida como metafísica intramundana, no sólo por su carácter englobante y totalizador, sino en cuanto manifestación suprema de la realidad ${ }^{8}$.

Considerar la realidad histórica como objeto de la filosofía implica reconocer la necesidad de un método adecuado para el conocimiento y el análisis de la realidad y la necesidad de una praxis transformadora. Pues la realidad es estructuralmente compleja y dinámica, una y diversa, cuantitativamente múltiple y cualitativamente diferenciada, contradictoria

8. Vale la pena una cita de Zubiri para ilustrar aquí el peso del maestro en el enfoque del discípulo. Se trata de un texto del prólogo que el autor preparó para la edición norteamericana de Naturaleza, historia, Dios, y que aparece en www.zubiri.org. El texto dice: "frente a estas cuatro gigantescas sustantivaciones, del espacio, del tiempo, de la conciencia y del ser, he intentado una idea de lo real anterior a aquellas. Ha sido el tema de mi libro SOBRE LA ESENCIA (Madrid, 19ó2): la filosofía no es filosofía ni de la objetividad ni del ente, no es fenomenología ni ontología, sino que es filosofía de lo real en cuanto real, es metafísica. A su vez, la intelección no es conciencia sino que es mera actualización de lo real en la inteligencia sentiente. Es el tema del libro que acaba de aparecer, INTELIGENCIA SENTIENTE" (Madrid, 1980). y estructuralmente injusta en su realidad actual.

El reto llevará necesariamente a sacar conclusiones en el ámbito intelectual y en la praxis, conscientes de que el devenir histórico implica un crecimiento de la libertad del ser humano, libertad que implica liberación paulatina de todo tipo de limitación u opresión contraria al propio ser, así como una mayor potencialidad de la vida personal y social de todos los seres humanos, es decir, de la Humanidad, en su proceso de realización en cuanto tal.

Planteado este panorama, se impone un paso más. Llegar a la reflexión teológica. De la mano de Sols diremos algunas palabras preliminares del aporte ellacuriano en el campo teológico.

Lo que en realidad pretendió Ellacuría, como otros de su generación, no era contagiar a la teología cristiana de marxismo - cosa de por sí muy difícil desde su formaciónsino construir lo que él denominó una "teología histórica". Aquí diremos una palabra de aproximación a esa realidad esencial dentro de lo que podríamos llamar el corpus del aporte de nuestro autor.

Por "teología histórica" Ellacuría entendía un modo de hacer teología: reflexionar acerca de la propia fe desde el presente histórico, y reflexionar acerca del presente histórico desde la fe. Él solía decir 
que toda teología -como también todo conocimiento humano en general- sea o no consciente de ello, está condicionada por su presente histórico.

En esta teología, el "locus theologicus" adquiere una gran importancia: desde dónde se reflexiona, para quién se reflexiona. Ellacuría y los teólogos de su generación quisieron hacerlo desde las mayorías oprimidas de América Latina y, en general, del Tercer Mundo.

\section{Qué es "lugar teológico"}

"Lugar" aquí tiene un sentido técnico teológico. Ecos, de Melchor Cano (1509-1560), llegan hasta aquí. Cano enseña en sus cursos y luego, mediante sus escritos -algunos publicados posmortem-, una verdadera novedad que, a la manera de la Lógica de Aristóteles, nacen con tal grado de perfección en la novedad que la obra posterior acerca de este tema sólo ha reproducido el De Locis Theologicis con algún pequeño retoque. Cuando Cano define lo que comprende por "lugar teológico", dirá que se trata de "locus unde (theologus) argumenta non quasi comuna et aliena, sed tamquam propria ducat, et suis dogmis confirmandis, et adversariorum sententiis refellendis"9. Son como domicilios de los argumentos teológicos, allí donde los teólogos encontrarán todas sus argumentaciones, sea para confirmar o sea para refutar. El mismo M. Cano enuncia diez locus ${ }^{10}$, aunque también deja claro que es muy probable que en el futuro haya teólogos que aumenten o disminuyan su número.

9. En traducción libre tendríamos: "lugares que le permiten al teólogo sacar argumentos, no en cuanto comunes y ajenos sino en cuanto propios, y con ellos a la vez confirmar sus dogmas y refutar las afirmaciones de los adversarios". Cano, M., De Locis Theologicis, en Opera Theologica, v. 1, Editrice Vera Roma, Roma, 1900, p.2.

10. Cf. M. Cano, op.cit., 1, p. 5-6. "El primer lugar es la autoridad de la Sagrada Escritura, contenida en los libros canónicos. El $2^{\circ}$ es la autoridad de las tradiciones de Cristo y los apóstoles; como no están escritas sino que llegaron a nosotros de oído en oído, se las llama con razón oráculos de viva voz. El $3^{\circ}$ es la autoridad de la Iglesia Católica. El $4^{\circ}$, la autoridad de los Concilios, especialmente de los Generales, en los que reside la autoridad de la Iglesia Católica. El $5^{\circ}$ es la autoridad de la Iglesia Romana que, por divino privilegio, es y se llama Apostólica. El $6^{\circ}$ es la autoridad de los santos antiguos (los $\mathrm{Pa}$ dres de la Iglesia). El $7^{\circ}$ es la autoridad de los teólogos escolásticos, a los que hay que añadir también los expertos en derecho pontificio. Porque la doctrina de este derecho corresponde, como $2^{\mathrm{a}}$ parte, a la teología escolástica. El $8^{\circ}$ es la razón natural, patente en todas las ciencias descubiertas gracias a la luz natural. El $9^{\circ}$ es la autoridad de los filósofos que siguen a la naturaleza como a su guía; entre ellos están, sin duda, los jurisconsultos imperiales, quienes también profesan la verdadera filosofía, como dijo el jurisconsulto. Finalmente, el último es la autoridad de la historia humana, sea que esté escrita por autores fidedignos, sea que haya sido transmitida de pueblo en pueblo, no de manera supersticiosa y como cuento de viejas, sino con razones de peso y con constancia". 
"Lugar", sin perder su condición de fuente a la que puede recurrir el teólogo para la argumentación idónea, no significa -en el discurso teológico de Ellacuría- un "espacio geográfico", sino que estamos en otra clave. "Lugar" significa, más bien, una "situación humana" desde la cual se informa el quehacer del teólogo. Desde allí, entonces, se realiza el esfuerzo argumentativo teológico propiamente dicho.

\section{El pobre como lugar teológico}

Desde la perspectiva de $\mathrm{M}$. Cano, nos explica O. González de Cardedal (1986: 45), hemos mirado el lugar teológico como aquel orden de realidad, de experiencia, de autoridad o de razón al que se puede pedir argumentos para demostrar afirmaciones teológicas y explicar cuál es la revelación de Dios y la fe de la Iglesia. El tratado de Cano fue, a partir del siglo XVII, sinónimo de tratado de apologética o de teología fundamental en las diversas cátedras de universidades y seminarios.

La irrupción de los que estaban ausentes y ahora comienzan a estar presentes, en una expresión muy cercana al modo de entender al pobre en Gustavo Gutiérrez, se da como una opción preferencial en la Iglesia latinoamericana luego de la conferencia de Medellín. Por opción se comprende solidaridad; la noción que hace referencia a la condición de lo preferencial hace pensar en la naturaleza de la pobreza que agobia a estas personas $\mathrm{y}$, finalmente, la pobreza misma habla de un mal que significa también muerte temprana e injusticia.

Leer esta realidad en clave teológica es lo que busca hacer nuestro autor, lo mismo que otros teólogos como, por ejemplo, Gustavo Gutiérrez $^{11}$ que lee la pobreza y al pobre como una realidad contraria al reino de vida anunciado por la revelación "jesuana".

La teología latinoamericana de la liberación, en sus diferentes expresiones, plantea un giro metodológico importante. Parte de una ubicación de cara a "la contextura real de los hechos", como decía Hugo Assmann (1973: 73). Así el teólogo se pregunta sobre qué palabra puede dirigir al pobre y luego qué palabra tiene éste que dirigirle. A continuación, el círculo hermenéutico tendrá que completarse y arrojar luces desde la revelación en la comprensión de los signos de los tiempos percibidos ${ }^{12}$.

11. Por ejemplo en Teología de la liberación. Perspetivas, Sígueme, Salamanca, p.357

12. Ellacuría en esta línea dirá: "Los pobres se convierten así en lugar donde se hace historia la Palabra y donde el Espíritu la recrea. $\mathrm{Y}$ en esa historización y recreación es donde 'connaturalmente' se da la praxis cristiana correcta, de la cual la teología es, en cierto sentido, su momento ideológico. Hay que reconocer que es fundamental, para la praxis 
Manteniendo cierta distancia de la reflexión tradicional teológica, Ellacuría entiende por lugar teológico varias cosas: lugar donde Dios se manifiesta para suscitar transformaciones, lugar donde el seguimiento es especialmente posible y, además, lugar idóneo para hacer reflexión teológica.

Si los pobres pueden ser -en la perspectiva ellacuriana- lugar teológico y lugar de salvación es porque Dios les ha escogido para invitar a cambios -si se quiere, para invitar a conversión- tanto de personas como de estructuras ${ }^{13}$.

Ahora bien, para Ellacuría, la pobreza que le ocupa requiriere de varios ingredientes para ser aceptable. "No basta cristianamente con ser 'materialmente' pobres. Hay que serlo también 'espiritualmente'. La espiritualidad no es aquí un sustitutivo de la materialidad, sino un coronamiento de la misma" (Ellacuría, 2000: 145).

y la teoría cristiana, el lugar de recepción, de interpretación y de interpelación, y hay que reconocer que ese lugar es, de modo preferencial y connatural, el lugar teológico que constituyen los pobres ya asumidos en su materialidad por el Espíritu de Jesús" Escritos teológicos I, p. 153.

13. "Los pobres en América Latina son lugar teológico en cuanto constituyen la máxima y escandalosa presencia profética y apocalíptica del Dios cristiano y, consiguientemente, el lugar privilegiado de la praxis y de la reflexión cristiana", I. Ellacuría, Escritos teológicos I, p.148.
Ellacuría es intenso en este punto. Para él el pobre se convierte, en este sentido, en una realidad de carácter absoluto, casi dogmático. Hablar de Iglesia de los pobres le resulta esencial y un calificativo que es como una nota más de la Iglesia. Y, dado que la noción de Reino es previa a la de Iglesia y los pobres son parte esencial del Reino, es claro que "en ellos se hace presente de modo insustituible el Dios cristiano, el destino de la humanidad y el camino de la conversión" (Ellacuría, 2000: 154).

\section{Ampliación sociopolítica del "círculo hermenéutico" bultmaniano}

Fue el teólogo alemán Rudolf Bultmann quien desarrolló en este siglo la hermenéutica bíblica existencial, esto es, la idea de que cada individuo sólo puede leer y entender la Biblia desde su situación personal existencial. De este modo, se produce un "círculo hermenéutico", o sea, un "círculo de interpretación", ya que el lector entiende la Biblia desde su presente existencial, y comprende su presente desde la Biblia.

Ellacuría, situándose en esa corriente hermenéutica, da un paso más: el lector no es sólo un individuo, sino un pueblo, al igual que el pueblo de Israel en el Antiguo Testamento. No se trata de 
menospreciar la experiencia personal (imprescindible, sin duda), sino de situarla en la experiencia de una colectividad.

El Nuevo Testamento no olvida la experiencia hebrea, sino que la radicaliza, la universaliza y la lleva a su cumplimiento. El Nuevo Testamento no acaba con este carácter comunitario de la fe, sino que lo radicaliza y lo universaliza.

Por ello, Ellacuría, ante la crítica que recibió la Teología de la Liberación de semitizar el cristianismo, esto es, de diluir lo novedoso del cristianismo en el judaísmo, contesta con un recurso a lo histórico.

El Nuevo Testamento no es un olvido del Antiguo. Dicho de otro modo, el cristianismo no es una destrucción del judaísmo, sino que es, como hemos indicado, su radicalización (ir a la raíz de la experiencia hebrea de Dios) y su universalización (llevar esta experiencia a todo corazón humano y a todo pueblo). $\mathrm{Y}$ añadimos ahora: es su cumplimiento.

El recurso a esta circularidad hermenéutica, permite a Ellacuría hacer una reflexión teológica que, partiendo de las fuentes de la revelación cristiana, suscita una reflexión que se actualiza en el lugar teológico por excelencia en el autor que estudiamos aquí, esto es: los pobres y ellos en cuanto que dan, a la postre, un valor especialmente intenso a la condición soteriológica del mensaje revelado del que inicialmente se parte.

\section{Inmerso en el "momento ideológico de la praxis eclesial"}

Así definía Ellacuría a la teología. Comprender adecuadamente la expresión obliga a tener presente el pensamiento ellacuriano como un pensamiento marcado por la praxis. De esta manera, hablar de praxis eclesial no es más que referirse al caminar de la Iglesia y su desempeño a través de hombres y mujeres que buscan reflejar un acontecimiento y un estilo de vida que es el propio de Cristo. Alvarado llega a definir "praxis eclesial" como "el caminar de la comunidad de los creyentes que, en medio de su devenir más global de la humanidad, intenta incidir en él de forma cristiana" (Sobrino-Alvarado, 1999: 131).

Y de ese andar la teología es momento ideológico en cuanto que aspira a ser todo lo contrario a un encubrimiento. Es la teología, así, un camino llamado a desideologizar un discurso que puede ser camuflaje de cosmovisiones legitimadoras no siempre con conciencia de serlo.

Más adelante Ellacuría dejará esta terminología y hablará de la 
teología como "una fe en busca de entendimiento" 14 .

\section{La teología histórica como propuesta teórica de cara a una utopía: la civilización de la pobreza. Las reflexiones del último Ellacuría}

Postrera y culminante, en 1991 aparecía en San Salvador la primera edición de Mysterium Liberationis y un año antes, en España. Allí aparece un artículo de Ellacuría que merece toda nuestra atención y al que recurriremos con frecuencia. Lo tituló Utopía y profetismo.

Antes de aparecer esta obra ellacuriana postrera, se habían dado a conocer dos escritos que aquí también miraremos. Uno aparecido en la Revista Latinoamericana de Teología en 1989 y que lleva por título "Utopía y profetismo desde América Latina. Un ensayo concreto de soteriología histórica". El otro fue un breve discurso pronunciado pocos días antes de su muerte en Barcelona con motivo de la concesión del Premio Internacional Alfonso Comín a la UCA y que apareció publicado en la revista ECA en el mismo 1989.

14. Esta expresión se usa en la Revista Latinoamericana de Teología que apareció en 1987 y que se recogerá en los Escritos Teológicos I de nuestro autor. Ese artículo se titula "La teología de la liberación frente al cambio socio-histórico en América Latina".
Con una impresionante clarividencia y coherencia en su cosmovisión, Ellacuría habla de un agotamiento en el modelo civilizatorio $^{15}$ que impone la riqueza e insiste en un dato: el modelo que se hace necesario debe partir del mundo pobre y sus características son las únicas capaces de evitar el colapso y la mortandad que se anuncia en el mundo pobre si las cosas siguen como se miran desde hace ya muchos años.

Ellacuría llega a las conclusiones que llega al intentar leer la realidad usando categorías heredadas de las influencias anteriormente indicadas, sobre todo del pensamiento de Zubiri. Contempla la realidad ${ }^{16} \mathrm{y}$ en ella identifica

15. Cuando Ignacio Ellacuría habla de civilización piensa en muchas cosas: primero, en un ser humano vertido y enfrentado a lo real con capacidad de crear capacidades y de apropiarse de posibilidades. Ese ser humano al tener la posibilidad de poder optar, lo hace. Y el producto de la acción de la especie humana -esto es, todos los que comparten el phylum humano común- hace resultar la civilización.

16. En la propuesta de Ellacuría, como ya se ha anotado en el contenido del presente texto, la máxima expresión de lo real es lo que él llama "realidad histórica". Ella incluye todas las dimensiones de lo real. Aparte de mostrar un realismo material abierto, Ellacuría plantea la materialidad de lo real, al ser humano en su centro en cuanto individuo con capacidad de interiorizar su "phylum" y de singularizarse respectivamente en cuanto vertido entre los demás. Presenta también una historia como proceso creacional en la 
dos coordenadas: una espacial que aporta la estructura y otra temporal que aporta la urgencia de un proceso. Lo que mira en su entorno concreto es una pobreza galopante en cuanto estructura compleja y lo que esa realidad real le sugiere, previo estadio de reflexión desde una inteligencia históricamente situada, es la necesidad de iniciar un proceso de praxis liberadora sustentada adecuadamente en una teoría o, si se prefiere, en un saber concreto sobre la realidad concreta. Así aparece ante los ojos de nuestro autor una realidad dinámica, siempre capaz de dar más de sí.

Ahora, cuando Ellacuría habla de "civilización de la pobreza" o incluso, a veces, de "cultura de la pobreza" -término que poco a poco deja de lado- oponiéndola a una "civilización de la riqueza o del capital", piensa en un conjunto de condiciones que, incluyendo una serie de elementos culturales, ha de ser capaz de revertir la historia, reescribirla desde otras categorías. Incluso algunos piensan que Ellacuría supo ir más allá del tiempo presente posmoderno al hacer referencias a su propuesta, de aquí que lo llamen "transmoderno". Un autor agregará que se trata de "una

que intervienen fuerzas y dinamismo diversos, además, claro está, del ser humano que interviene mediante la praxis. transmodernidad que -superadas la fe en la Razón absoluta hegeliana y la marxista fe absoluta en la razón- recupera, sin embargo, la necesidad de racionalidad y razonabilidad desde una visión integral del hombre, de la sociedad y la historia. La recuperación de lo humano supone reconciliación de lo material y espiritual del hombre, de su ser racional y de su naturaleza sensible. La dualidad humana queda superada en sus realizaciones, que combinan fuerza, sentimiento, razón, instinto y pasión, y por ello mismo resultan ser obras humanas y humanizadas" (Rivera, 1997).

\section{Utopía y profetismo}

Ellacuría aborda la presente cuestión refiriéndose a la urgencia de siempre "historizar" cuanto se proponga. Y así procede, ubicándose en América Latina, y descubriendo en el profetismo un método y en la utopía un horizonte.

Desde su perspectiva cristiana empieza afirmando cómo "la utopía cristiana sólo puede ser construída desde el profetismo y el profetismo cristiano debe tener en cuenta la necesidad y las circunstancias de la utopía cristiana" (Ellacuría et al., 1993: 394).

Esta utopía que se propone hunde sus raíces en la tradición bíblico-teológico-magisterial de la Iglesia y encuentra su punto de 
llegada en la noción de Reino de Dios, en cuanto meta que se ha de concretar poco a poco y a partir de pasos concretos que hagan suponer que los esfuerzos que se realizan se dirigen en esa dirección y no en otra. El profetismo no será otra cosa sino "la contrastación crítica del anuncio de la plenitud del Reino de Dios con una situación histórica determinada" (Ellacuría et al., 1993: 396). Es de esta manera cómo se ponen de manifiesto las limitaciones y los males de una determinada situación histórica y se indica el camino de futuro que se da de andar en cuanto superación real del presente. Como se ve la interacción entre la utopía propuesta y el profetismo que la anima y apresura es decisiva, incluso en cuanto posibilidad de hacer actual lo que la utopía plantea sólo como una posibilidad histórica.

En otro lugar, Ellacuría escribirá que "América Latina es hoy un lugar privilegiado de profetismo y utopía, aunque todavía la actualización de su potencialidad profética y utópica esté lejos de ser satisfactoria" (Ellacuría et al., 1993: 399). Nos ubicamos ante una zona maltratada, contrastante, con una fuerte voluntad de liberación y con una visión utópica -plenamente consciente en muchos de sus sectores sociales y eclesiales- que hace ver que no es la utopía que ofrece el mundo desarrollado la que mira como deseable.

Luego nuestro autor escribirá que "el profetismo utópico apunta a una nueva forma de libertad y humanidad mediante un proceso histórico de liberación" (Ellacuría et al., 1993: 402). Y todo esto mirado desde la América Latina es especialmente intenso. Cuando Ellacuría escribía sus reflexiones, la región que contemplaba era el escenario del entrecruce de todo tipo de intereses externos e imperialismos vigentes a la fecha. En su momento tanto la teoría de la dependencia como la teología y filosofía de la liberación lo ponían en claro y lo explicaban en detalle, haciendo mirar lo injusto de fenómenos decisivos como la deuda externa y sus consecuencias, lo mismo que la barbarie generada por la insolidaridad propiciada por los choques ideológicos de moda y las injusticias fácilmente constatables en su momento.

Ellacuría hace ver cómo, a pesar de que la Iglesia ya venía condenando por igual los dos grandes sistemas imperialistas imperantes en ese tiempo, el énfasis era claro: la dinámica de un sistema concreto, como el capitalismo, con todos sus efectos, esto es, su capacidad para fomentar dependencias e imponer patrones culturales, su eficacia para suscitar consumo, insolidaridad e individualismo; en fin, su "ferocidad depredatoria" que sólo aspira 
a sanar superficialmente el daño causado en los pueblos agredidos con la promesa vana de una democracia ideologizada y promesas de un nivel de vida que no es universalizable, ni siquiera materialmente, ni tampoco deseable, dadas sus evidentes y nefastas consecuencias en términos de temores, inseguridades y pérdida de sentido.

De cara a todo esto, la Iglesia está llamada a decir su palabra, una labor que ha cumplido de un modo más o menos regular y más o menos unánimemente. Una palabra profética que siempre ha de contar con el horizonte planteado por el ideal del Reino de Dios como proyecto siempre inacabado. Ahora, ¿qué se debe proponer? ¿Qué decir para plantear con realismo un proyecto global universalizable y no uniformizante que sepa respetar lo propio de cada pueblo sin obviar las necesidades que cada ser humano tiene de un nivel de vida de calidad? ¿Es viable una universalización que parte de los pobres -más cristiana de paso- capaz de ir más allá de una opción por la riqueza que ha provocado más mal y angustia que bien? ¿Es posible un empezar de nuevo a partir de un orden más liberador y promotor de la dignidad del ser humano, de todo él y de todos y en clave más cristiana? ¿Es el profetismo de la liberación el recurso decisivo para promover la utopía de libertad que se sueña?
Ellacuría llega así a formular una síntesis con amplios ecos escriturísticos que reza así: "la utopía cristiana prenuncia de una manera histórica la creación del hombre nuevo, de la tierra nueva y del cielo nuevo" (Ellacuría et al., 1993: 419). El primer concepto implica un ser humano en protesta activa y lucha permanente, nuevo por su actitud constructiva y sin odios, sin más proyecto que el de un mundo caracterizado por la justicia. Es un hombre que sabe vivir de la esperanza activa, que no hace de nada finito un valor absoluto y sabe estar en paz consigo mismo, con los demás y con Dios mismo.

La tierra nueva soñada implica la utopía de un nuevo orden económico, un orden social novedoso y un orden político y cultural marcado por una propuesta que más allá de lo de siempre, esto es, de un modelo que, considerado salvador, dejó marcado el continente por una miseria de las más dolorosas. Aquí llegamos a lo que estábamos buscando.

El nuevo orden económico supone una civilización de la pobreza que sustituya la actual civilización de la riqueza. Una propuesta de raíces cristianas que invita a ir más allá de las cosas y del economicismo materialista por ser éste altamente inaceptable desde la perspectiva ética, tanto por su dinamismo interno como por sus 
resultados. ¿La alternativa? Ellacuría propone un humanismo materialista en el que la materia humana, compleja y esencia abierta, es el elemento determinante.

Esta propuesta implica un pasar de la sola acumulación de riqueza para optar por la satisfacción de las necesidades básicas como principio decisivo de desarrollo y humanización. Hablar de civilización de la pobreza no es promover la pauperización general, sino promover un dinamismo diferente que supera la lógica que lleva a absolutizar el binomio capital-riqueza, que lleva a enfrentar la centralidad de la acumulación desde una nueva concepción del trabajo como vía de perfeccionamiento y no como actividad promotora de explotación y de profundización de brechas entre los que tienen y los que no. Estamos ante una concepción de la vida que además resulta ser altamente solidaria y con un uso de cuanto se posee con una dimensión social muy en coherencia con la enseñanza social de la Iglesia planteada así desde el inicio de sus formulaciones en 1891.

¿Algún auxilio adicional? Ellacuría siempre en su escrito en Mysterium liberationis, a la par que cree viable la utilización de algunos instrumentos de cuño socialistas, muy pronto duda y dirá que "el profetismo y la utopía cristiana necesitan ser críticos de la teoría y de la práctica de los sistemas económicos dominantes" (Ellacuría et al.., 1993: 431), sin ingenuidades y de cara a un detalle de realidad evidente: la expansión y universalización de la civilización de la riqueza. Acaba Ellacuría el texto que aquí nos ocupa haciendo un repaso de otros puntos que se miran en el ideal que se desea construir. Un orden social nuevo con una sociedad civil más consciente y activa. Un orden político que sepa ir más allá de las posiciones que él miraba enfrentadas en su tiempo y un orden cultural que, sabiendo vivir las riquezas propias y el ideal humanizador, sepa defenderse de lo que se viene: la unificación en torno al consumo y al uso masivo y masificador de los medios de comunicación. ¿La meta final? Los cielos nuevos. Mas Ellacuría no se queda en la pura contemplación escatológica. Es consciente de la necesidad de mantener siempre cierta tensión entre ese fin al que se tiende y el presente. En esta lógica están también otras propuestas que han tenido su impacto en la reflexión teológica del siglo XX, sobre todo, en la clave de los trabajos de J.B. Metz y su teología política y de J. Möltmann y su teología de la esperanza ${ }^{17}$. Se

17. Sobre estas posiciones se puede recurrir a cualquier historia de la teología del siglo XX. Podemos sugerir de Illanes, J., Saranyana, J.I., Historia de la teología, BAC, Madrid, 1995. Lo mismo que Gibelini, R., 
trata de posiciones que insisten en un dato: lo que viene se construye hoy y en la motivación está Aquel que hace nuevas todas las cosas.

\section{El desafío de las mayorías pobres}

En plan de recibir el Premio Internacional Alfonso Comín, el 6 de noviembre de 1989, Ellacuría pronunció las palabras que aquí queremos mirar.

En esa ocasión Ignacio Ellacuría empezó recordando que ninguna praxis transformadora eficaz de cara a la sociedad podía prescindir de la teoría. A la vez que recordaba el gran compromiso que en esta dirección tenía el mundo académico universitario, sobre todo cuando él es consciente de sus compromisos de cara a las grandes mayorías empobrecidas que exigen, día a día, que alguien dé con el camino que revierta el modo en que se configura la civilización. Se trata de ir más allá de la civilización de la riqueza y de sus consecuencias más evidentes:

- ampliación de la brecha entre pobres y ricos a todo nivel;

- endurecimiento de los procesos de explotación y de opresión;

La teología del siglo $X X$, Sal Terrae, Santander, 1998.
- deterioro de la ecología a nivel planetario;

- deshumanización progresiva de masas que, optando por el tener, se olvidan del ser.

La tarea es gigantesca, dirá Ellacuría, para la cual se requiere una gran esperanza y un esfuerzo muy serio por "alimentar y provocar una conciencia colectiva de cambios sustanciales" (Ellacuría, 2000: 360). Y, además, aportar constructivamente lo que se pueda. Es lo que, y ello afirmado de modo redundante, nuestro autor dice hacer con el concurso de la Universidad de la que era rector en ese momento. La UCA se erigía como un centro de estudios con una opción clara en favor de las mayorías y con una dedicación constante a la gran tarea que corresponde a la Universidad desde su medieval nacimiento: "encontrar la verdad de lo que está pasando y la verdad que entre todos debemos buscar y construir" (Ellacuría, 2000: 362). Un compromiso que se planteaba en términos revolucionarios en clave universitaria y que implicaba un trabajo de reflexión que hiciera ver cómo -sobre todo, pensando en la UCA como en un centro de estudios superiores de inspiración cristianafe y justicia son "dos realidades mutuamente referidas o respectivas, que forman o deben formar una única totalidad estructural, tal 
y como repetidamente se ha expresado en la teología de la liberación y en otros movimientos teológicos afines" (Ellacuría, idem).

\section{Lectura actual}

Dicho lo anterior, podríamos animarnos a ensayar alguna relectura contextualizada de lo anotado por nuestro autor. ¿Cómo asumir la propuesta de Ellacuría desde nuestro hic et nunc? En medio de nuestra realidad, inmersos en esta sociedad global y marcada por algunos por el fenómeno de la información en la que algunos se han empeñado en que vivamos, ¿tiene algún sentido hablar de modos de vida que se desvinculen de la estética omnipresente del consumo? ¿Tiene sentido hablar de límites en un contexto que ha mostrado las consecuencias de la falta de éstos?

\section{- ¿Un horizonte utópico con sentido hoy dia?}

El hecho de que hoy día haya crisis de utopías no significa que dejen de ser necesarias o posibles. Incluso deberíamos hoy buscar la manera de devolver un lugar a la esperanza utópica y enfrentar así el ascenso de tanta mediocridad, falta de reflexión o conformismo, o bien, si se prefiere, se trata de enfrentar el triste modo en que lo insignificante o lo efímero se apodera de todo y lo corrompe todo ${ }^{18}$.
El actual orden (¿desorden?) mundial nos muestra un horizonte que está muy lejos de ser un panorama atractivo para todos. Al menos para las tres cuartas partes de los seres humanos es claro que sería preferible vivir en condiciones mejores que las presentes, para no decir nada de los casi mil setecientos millones de personas que, literalmente, agonizan día a día con ingresos menores que un dólar diario.

Ya hace varios años ${ }^{19}$ que Alvin y Heidi Toffler habían hablado de que globalización y liberalización no eran lo mismo, además que la globalización no era necesariamente inevitable ni creaba campos nivelados y añadían que la globalización mataba la democracia y que ella no era buena para todos. Hoy les damos la razón con creces.

Cada año que pasa el PNUD y UNICEF nos recuerdan un panorama mundial en el que el ochenta por ciento de los seres humanos sobran $^{20}$. Incluso en su momento J.D.

18. Sobre esto vale la pena mirar algunas de las obras de C. Castoriadis como El ascenso de la insignificancia (Frónesis, Madrid, 1998) y La insignificancia y la imaginación (Trotta, Madrid, 2002).

19. Interesante lo que, sobre este tópico, se decía en el artículo periodístico titulado Mitos del globalismo, La Nación, 1 nov. 1998, p.16A.

20. Recientemente I. Ramonet ha dicho el pasado 4 de set del 2002: "En la era de la globalización, la terrible realidad social de nuestro planeta es que hay apenas unos 500 millones de personas que viven como un europeo me- 
Wolfensohn llegó a reconocer que "vivimos en un mundo marcado por la desigualdad". Y más adelante agregaba: "algo anda mal cuando el $20 \%$ más rico de la población mundial recibe más del $80 \%$ del ingreso mundial" ${ }^{21}$. De 6.55 millones de habitantes en el planeta, según datos del 2008, 5.1 millones viven en países en vías de desarrollo y 850 millones de seres humanos padecen hambre cotidianamente según el informe de Catholic Relief Services ${ }^{22}$.

$\mathrm{Y}$ los que bien viven, ¿qué panorama presentan? Castoriadis hace una lectura dura de lo que él mira: "en ellas (esto es, las sociedades occidentales) el único valor es el dinero, la notoriedad mediática o el poder, en el sentido más vulgar y más despreciable del término". Ubica un "vacío total de significación" (1996: 63) en esas naciones que podríamos llamar "premiadas" por la globalización selectiva y excluyente que nos envuelve y que, adicionalmente, nos parece necesario llamar,

dio, mientras que los que se encuentran en la necesidad son ¡5.500 millones!” (ver los detalles del artículo en la dirección http:// www.forumsocialmundial.org.br/dinamic. asp?pagina=ramonet_esp )

21. Hacia un mundo con equidad, Discurso en Praga, 26 sept. 2000, ubicable en el siguiente lugar de la web: www.worldbank.org/html/ extdr/am00/jdwsp/jdwsp-es.htm

22. Según datos que aparecen en http://www. foodfast.org/resources/sp/poverty-hungerdata_esp.pdf con Benedicto XVI, insolidaria (Caritas in Veritate, 19).

Dado esto, ¿valdrá la pena asumir el paradigma de desarrollo occidental? Muchos autores piensan que ello se impone del modo más obvio; otros, en cambio, piensan negativamente al respecto. Esa vía civilizatoria no es, en criterio nuestro, la más correcta. No parece ser la vía ideal el proceder a un "patrón civilizatorio mundializado" 23 al cual la mayoría no tiene más que un acceso virtual. En esta línea está la propuesta de Ellacuría que arriba tratamos de explicar.

Hacer alguna propuesta parece útil en las presentes circunstancias. Y si esa propuesta es algo radical, si encarna el ideal que se esconde tras la etimología de la expresión utopía, aún mejor.

- ¿La civilización de la pobreza como opción de cara a la necesidad presente de un desarrollo limitado?

Hoy día, sin embargo, la urgencia de salidas se impone. Poco a poco, hay ideas que parecen tomar impulso y se imponen como urgentes por las urgencias de sus propias

23. Expresión ésta que usa R. Ortiz en Otro territorio (Convenio Andrés Bello, Bogotá, 1996), p.13, para referirse al imaginario colectivo común que hoy trata de imponerse y que no es otra cosa que una manera de imperialismo cultural en clave de "americanización". 
razones. Es el caso de la idea de que el crecimiento o desarrollo implica límites. Esto es, que no es suficiente con poder. Es esencial descubrir si conviene poder y si conviene para todos. En esta clave, nos damos cuenta de que la propuesta ellacuriana, en cuanto invitación a ir más allá de una comprensión del desarrollo sin límite alguno y girando en torno al único ideal consumista, fue, efectivamente, levantar la voz proféticamente y adelantarse a conclusiones que apenas comenzaban a parecer evidentes.

¿Hay realmente un límite al crecimiento, una barrera imposible de atravesar? Algunos científicos afirman que estamos corriendo hacia un precipicio y que debemos interrumpir inmediatamente nuestro esfuerzo de crecimiento, al menos con las presentes características excluyentes y al actual ritmo de deterioro del medio.

En 1970, el Club de Roma, una asociación privada compuesta por empresarios, científicos y políticos, encargó a un grupo de investigadores del Massachusetts Institute of Technology, bajo la dirección del profesor Dennis L. Meadows, la realización de un estudio sobre las tendencias y los problemas económicos que amenazan a la sociedad global. Los resultados fueron publicados en marzo de 1972 bajo el título Los Limites del Crecimiento.
En el estudio se utilizaron las técnicas de análisis de dinámica de sistemas más avanzadas del momento. En primer lugar se recopilaron datos sobre la evolución que habían tenido en los primeros setenta años del siglo XX un conjunto de variables: la población, la producción industrial y agrícola, la contaminación, las reservas conocidas de algunos minerales. Diseñaron fórmulas que relacionaban esas variables entre sí -la producción industrial con las existencias de recursos naturales, la contaminación con la producción industrial, la producción agrícola con la contaminación, la población con la producción agrícola, etc.- y comprobaron que esas ecuaciones sirvieran para describir con fidelidad las relaciones entre los datos conocidos que habían recopilado. Finalmente introdujeron el sistema completo en un ordenador y le pidieron que calculase los valores futuros de esas variables.

Las perspectivas resultaron muy negativas. Como consecuencia de la disminución de los recursos naturales, hacia el año 2000 se produciría una grave crisis en las producciones industrial y agrícola que invertirían el sentido de su evolución. Con algún retardo, la población alcanzaría un máximo histórico a partir del cual disminuiría rápidamente. Hacia el año 2100 se estaría alcanzando un estado 
estacionario con producciones industrial y agrícola per cápita muy inferiores a las existentes al principio del siglo XX, y con la población humana en decadencia.

El equipo del MIT introdujo entonces modificaciones en los supuestos iniciales para estudiar cómo podría ser modificado ese resultado final. El supuesto de que las reservas mundiales de recursos quedasen multiplicadas por dos o por cinco tan sólo significaba un retraso de apenas diez o veinticinco años en el desencadenamiento final de la crisis. Esta vendría acompañada de tasas de contaminación mucho más altas y la mortandad consiguiente reduciría la población humana incluso a niveles inferiores a los de la secuencia-tipo, esto es, del ideal. La introducción de controles sobre el uso de recursos, la producción de contaminantes y la natalidad, tampoco conseguirían impedir el colapso final ${ }^{24}$.

La única modificación de los datos introducidos en el ordenador que conseguía eliminar la crisis consistía en la igualación inmediata de las tasas de natalidad y mortalidad en todo el mundo, la detención del proceso de acumulación de capital y el destino de todas las inversiones

24. De gran interés las reflexiones que aparecen en www.eumed.net acerca de crecimiento y desarrollo éticamente aceptable. exclusivamente a la renovación del capital existente, modernizándolo para un uso más ahorrador de recursos y menos contaminante. Pero ese frenazo brusco en el crecimiento de la población y del capital debía producirse, según los autores, inmediatamente, antes del año 1985.

Poco después de publicarse el informe del Club de Roma, los precios del petróleo y de las materias primas se dispararon y los países occidentales se hundieron en la crisis económica más grave y prolongada que habían conocido desde la Segunda Guerra Mundial. Muchos pensaron que aquellas sombrías previsiones estaban a punto de cumplirse, antes de lo estimado. Fue la época del nacimiento de un gran número de organizaciones ecologistas y de teorías sobre el crecimiento cero.

Sólo recientemente las aguas han vuelto a su cauce. La crisis de los años setenta fue mala pero no fue la última. Los precios del petróleo y las materias primas subieron y volvieron a bajar. No faltan quienes piensan que la voz de alarma fue sólo un susto superado. Otro avisan en la otra dirección: hay que atender las advertencias y a las señales que, luego del 2008, han ido apareciendo en el mapa económico mundial.

¿Así pues, resulta o no la propuesta ellacuriana viable de cara a estas reflexiones? No faltarán 
quienes piensen en alguna manera de leer el ideal propuesto por Ellacuría como el de algún ingenuo o falto de realismo. Sin embargo, recorre hoy nuestra inteligencia una cierta certeza de que el estilo de vida desarrollado, esto es, la "americanización", no tiene que ser el único camino para que la realidad dé más de sí, lo mismo que la idea de que el consumo desembocado no ha de ser siempre y necesariamente la vía prototípica por recorrer toda la humanidad. Incluso habría que decir que visiones tan temerosas del futuro de autores como Hans Jonas encuentran sus puntos de partida en los signos oscuros que aquí y allá deja ver el ser humano desarrollado y su estilo de vida. Un hombre siempre dispuesto a acabar con lo que lo rodea con sólo una mala decisión.

\section{- El realismo de una propuesta en tiempos del presente "desorden" global.}

Ignacio Ellacuría puede que plantee en su propuesta aspectos más o menos cuestionables, más o menos según sea el parecer y el modo de ver las cosas de quien se acerque a su pensamiento, pero si hay algo que no se le puede endilgar es que no sea realista. Su formación zubiriana le impide cualquier idealismo y su experiencia de vida aún más.

Escribe nuestro autor en un texto bastante englobante: "en el orden económico la utopía cristiana, vista desde América Latina, que surge del profetismo real historizado en una situación determinada, propone una civilización de la pobreza, que sustituya a la actual civilización de la riqueza" (Ellacuría, 1989: 169). Esa novedad resulta esencial y radical por cuanto implica hacer centro la satisfacción de la necesidades de todos y el fomento de una solidaridad global suscitadora de una fuerza humanizadora nueva.

¿Alguien podría considerar que esta propuesta sea innecesaria? Por otra parte, que no haya voluntad política desde los centros del poder, no hace superflua una idea que ya antes de la década de los noventa hacía ver la urgencia de repensar muchas cosas y que llamó a una verdadera "solidaridad globalizada" 25 . En continuidad han venido surgiendo diversas propuestas.

Empecemos mostrando con una larga y justificada cita, lo que ocurrió del 1 al 3 de marzo del 2000. Por esos días se reunió en La Habana, Cuba, el Foro titulado "Las ONGs del Sur y los retos de la globalización" que contó con la presencia de delegados de ONGs y

\footnotetext{
25. "En definitiva, el desafío -como escribía el Papa en el Mensaje para la Jornada Mundial de la Paz 1998- consiste en asegurar una globalización en solidaridad, una globalización sin dejar a nadie al margen" (n.3).
} 
organizaciones sociales de 44 países de América Latina y el Caribe, Asia, África y Medio Oriente. Allí se dijeron muchas cosas, pero para nuestro propósito nos interesa de su declaración final, una reflexión que viene al final, luego de las constataciones. Los participantes en este foro indicaron:

"Por nuestra parte, los delegados a este Forum, conscientes de las adversas circunstancias en que se desarrolla la lucha de nuestros pueblos por sus más sentidas reivindicaciones (...):

* Reclamamos una participación mayor y exigimos un más alto grado de transparencia de los gobiernos e instituciones internacionales en los procesos de toma de decisiones sobre problemas que nos atañen directamente y que en muchas ocasiones tienen efectos devastadores en términos del incremento de las desigualdades, la pobreza y el desempleo.

* Demandamos la profundización de las relaciones de integración económica, cultural y social entre los países del Sur para fortalecer su capacidad de acción como región ante los retos de la globalización.

* Reafirmamos la disposición y la capacidad de las ONGs y de los más amplios sectores sociales para influir en el diseño de estrategias, en la implementación de acciones y en la gestión de recursos a favor del desarrollo social de nuestros países.

* Nos convocamos a estrechar los lazos de cooperación entre nuestras organizaciones, potenciando los elementos que nos unen, en defensa del derecho al desarrollo, que concebimos como un derecho humano fundamental; y a exigir a los gobiernos el cumplimiento de sus compromisos con las necesidades y el futuro de nuestros pueblos.

* Ratificamos nuestra convicción en que, frente al dominio avasallador alcanzado por las corporaciones transnacionales en los umbrales del nuevo milenio y ante la alarmante realidad de que estas experimentan un crecimiento mucho mayor que la economía mundial en su conjunto, amenazando con su poder la soberanía y el derecho al desarrollo de los países del Tercer Mundo; nuestra respuesta no puede ser otra que la de profundizar la lucha, la unidad y la solidaridad, con apego al respeto por la diversidad que nos caracteriza y tanto nos enriquece, construyendo alternativas por un mundo mejor.

Globalizar la solidaridad no es una intención, es la única forma de enfrentar, con éxito, los males de hoy y los retos del mañana"26.

26. Se puede mirar el texto completo y los comentarios anexos en la dirección electrónica http://servicioskoinonia.org/logos/ $\log 0$ 056.htm 
François Houtart, otro ejemplo del Centre Tricontinental Foro Mundial de las Alternativas, comentando los resultados del Foro Social Mundial en Porto Alegre, descubre un dato esencial: se está pasando de la seguridad de que no hay alternativas a la certeza de que debe haber algún camino alterno al capitalismo global.

El entorno muestra el inicio de un mundo en reacción. El mismo Houtart propone una vía doble: "Se puede pensar a dos orientaciones principales: la contemplación de la naturaleza y la solidaridad interhumana" ${ }^{27}$.

27. El artículo se titula El estado actual de la globalización y los temas para el Foro Social del 2002, ubicable en http://www.forumsocialmundial.org.br/dinamic/es/houtartpor2.asp Allí el autor insiste y describe así su propuesta: "1- El respecto, amor y contemplación de la naturaleza Retomando grandes textos de las tradiciones religiosas del mundo, incluyendo las religiones autóctonas (la Pacha Mama) ; los grandes mitos de la creación ; los textos de los poetas de varios pueblos, se podría afirmar que la naturaleza no es un objeto de explotación, sino que somos parte de ella y que queremos expresar un sentido de admiración y de contemplación. Eso se podría expresar por cantos, danzas, recitaciones, participación de todos en un acto colectivo. 2- La solidaridad interhumana. Se podria encontrar en las mismas tradiciones culturales y religiosas, todo lo que celebra la fraternidad, el amor, la paz, el rechazo de la agresividad y de la violencia, como también del individualismo económico. No se trata de celebrar de manera romántica este tipo de valores, sino de referirse a las relaciones sociales concretas del capitalismo y todas sus consecuencias humanas y expresar tam-
Por otra parte, aunque en la misma línea, hace algún tiempo el Cardenal Martini había dicho: "La esperanza es que -mediante una articulada y difundida elaboración cultural orientada a implicar no sólo al mundo académico sino también a las diversas expresiones de la sociedad civil- se pueda contribuir a diseñar nuevos escenarios en los cuales el fenómeno de la globalización, lejos de convertirse en timón para ulteriores y más graves formas de exclusión, marginación y conflicto, pueda presentarse de hecho como una cara de esa interdependencia que caracteriza cada vez más a nuestra convivencia. Y, sobre todo, pueda favorecer una interpretación virtuosa de la misma interdependencia, transformándola en auténtica solidaridad, premisa y garantía de paz para todos" (Martini, 1999).

Finalmente, y en este mismo tono de propuesta utópica, el Movimiento de los Focolares lanzó hace algunos años la propuesta que ha recibido impresionante acogida y que se llamó en su momento "economía de comunión" ${ }^{28}$ y que

bién la necesidad de una ética nueva para un nuevo mundo".

28. Una de las primera propuestas se expone en la revista Ciudad Nueva, (2000) n. 2, p. 8. también es interés la entrevista a L Bruni, miembro del grupo Cristianos por Europa y que aparece en la dirección http://es.catholic. net/empresarioscatolicos/484/1049/articulo. php?id=10906 
hoy se profundiza como una propuesta alternativa al modelo imperante, que se extiende poco a poco y que tiene como objetivo general la gestación de una actitud que sea capaz de difundir mundialmente una cultura de dar ${ }^{29}$. Esta experiencia y otras del Movimiento Comunión y Liberación en Europa, al releer el principio de subsidiaridad (en la misma línea que lo hace Benedicto XVI en Caritas in veritate) y en América Latina al acercarse al Movimiento de los Sin Tierra, muestra una vitalidad inusitada del cristianismo al iluminar un ideal de economía con rostro humano en la clave tan conocida de Amartya Sen y Bernardo Klinksberg ${ }^{30}$

29. Sobre esto es de interés el artículo Aqui se enseña la 'cultura de dar', Ciudad Nueva (2002) n.5, p.16 ss.

30. Amartya Sen y Bernardo Klinksberg reflexionan en Primero la gente (Deusto Ediciones, 2009) sobre algunos de los principales problemas del mundo globalizado y examinan algunas de las principales soluciones en torno a éstos. Para hacerlo, aplican la perspectiva de una reciente disciplina que despierta actualmente gran atención: la ética del desarrollo o el desarrollo ético: Esta disciplina pretende recuperar la relación perdida, en opinión de los autores, entre ética y economía. El texto en cuestión nos presenta: Primera parte: Temas claves del siglo XXI; ¿Cómo juzgar la globalización? Exclusión e inclusión; ¿Cuál es el propósito de la democracia?; Por qué debemos preservar la "Lechuza Moteada”; ¿Por qué la equidad en salud?; La mortalidad como indicador económico; Segunda parte: Los desafíos éticos abiertos en un continente paradojal; América Latina; El caso de la salud pública; Mitos
Valdría la pena cerrar con un texto de Tony Mifsud (2002), director en ese momento del Instituto de Ética de la Universidad Alberto Hurtado de Chile, cuando decía: "una cultura de mercado entra en contradicción con el ethos solidario al cosificar las relaciones humanas (el valor social del ser humano se basa en su capacidad adquisitiva), colocando el afán por el acumulo por encima del compartir (el más se erige en criterio excluyente), reduciendo el espacio del encuentro en apenas una plaza de intercambio (la mentalidad predominante del yo doy para que tú me des). Por el contrario, una cultura solidaria piensa en términos de crecimiento con equidad, en un proceso de siempre mayor acceso a la igualdad de oportunidades".

¿Utopías inalcanzables? Puede que sea así, pero nada se pierde con soñar y, curiosamente, todo se puede ganar, recordando la ya muy conocida expresión de Blas Pascal.

\section{Conclusión}

Incluso vitalmente, Ellacuría se mostró siempre convencido de

sobre la juventud latinoamericana; ¿Cómo enfrentar el crecimiento de la inseguridad; ¿Ciudadana en América Latina?; Las lógicas en conflicto; ¿Por qué la cultura es clave para el desarrollo?; Siete tesis sobre el voluntariado en América Latina; Una reflexión adicional; El impacto de las religiones sobre la deuda ética-social actual. 
que el pobre es mucho más que sólo una categoría teológica y que la civilización de la pobreza era mucho más que sólo un ideal realizable. Ha quedado arriba indicado.

Él, que supo detenerse en todas la implicaciones de estos conceptos (socio-económicas, dialécticas, políticas, éticas y teológicas), pudo concluir que "cuando los pobres ocupan el lugar que les corresponde en la Iglesia, la institución eclesial se llena de espíritu" (Ellacuría, 2000: 192) y que ella misma, en la medida en que lo logre, pasa a ser promotora de solidaridad, de una nueva civilización que, perfectamente, podríamos llamar civilización del amor -en la clave de Pablo VI- o bien, civilización del trabajo o de la pobreza, como se ha anotado.

Y nuestro autor vivió siempre convencido en esta dirección. Y convencido de ello hasta las últimas consecuencias. El sabía perfectamente que el sentido de la historia se buscaba intramundanamente; de ahí su empeño vital por hacerse cargo, encargarse y cargar con la realidad. Su honestidad con lo real lo llevó a donde, finalmente, llegó.

\section{Bibliografía}

AAVV. (1995). Para una filosofía liberadora, UCA edic., San Salvador.

AAVV. (2002). A trece años, nunca más: Ignacio Ellacuría, ITAC, San José.
Alvarado, J. (1993). Vida y pensamiento de Ignacio Ellacuría, en A. González (ed.), Voluntad de vida: ensayos filosóficos, Seminario Zubiri-Ellacuría, v.1, Managua.

Burke, K. (2000). The ground beneth the cross, Georgetown Univ. Press, Washington D.C.

Cardenal, R. (1999). Biografías, Mártires de la UCA, CMR, San Salvador.

Ellacuría, I. (1973). Teología política, Ediciones Secretariado Social, San Salvador.

(1990). Quinto Centenario de América Latina, Cristianismo i Justicia, Barcelona.

(1993). Veinte Años de historia el El Salvador (1969-1989). Escritos Políticos, 3 v., UCA edic., San Salvador.

(1984). Conversión de la Iglesia al Reino de Dios, Sal Terrae, Santander. (1993). Mysterium liberationis, 2 v., UCA edic., San Salvador.

Escritos filosóficos vv. I (1996), II (1999), III (2001), UCA edic., San Salvador.

(1999). Filosofía de la realidad histórica, UCA edic., San Salvador. (1999). Escritos universitarios, UCA edic., San Salvador.

Escritos teológicos, vv. I (2000), II (2000), III (2002), IV (2002), UCA edic., San Salvador.

(1999). Sobrino, J., Fe y justicia, Desclée, Bilbao. 
Flores, V. (1997). El lugar que da verdad, UIA, México.

Floristán, C. (1993). Tamayo, J.J., Conceptos fundamentales del cristianismo, Trotta, Madrid.

Gimbernat, J. (1994). Gómez, C., La pasión por la libertad, Verbo Divino, Estella.

Martialay, R. (1999). Sangre en la Universidad, Mensajero, Bilbao.

Mora, J. (2004). Ignacio Ellacuría, filósofo de la liberación, Nueva Utopía, Madrid.

Senent, J. (1998). Ellacuría y los derechos humanos, Desclée, Bilbao.

Sobrino, J. (1999). Alvarado, R., Ignacio Ellacuría. "Aquella libertad esclarecida”, Sal Terrae, Santander.

Sobrino, J. (2001). Ignacio Ellacuría, el hombre y el cristiano, CMR-UCA, San Salvador.

(2005). entrevista en el campus de la UCA en julio.

Sols, J. (1999). La teología histórica de I. Ellacuría, Trotta, Madrid.

Whitfield, T. (1998). Pagando el precio, UCA edic., San Salvador.

\section{Artículos, ponencias}

Berríos, F. (2004). El método antropológicotrascendental de K. Rahner como hermenéutica teológica del mundo y de la praxis, Teología y Vida, XLV.

Corominas, J. (1998). Ellacuría y X. Zubiri: la pasión por la verdad, Proceso, 830.

Ellacuría, I. (1989). Utopía y profetismo desde América Latina, Revista Latinoamericana de Teología, 17.
(1982). Auténtico lugar social de la Iglesia, Misión Abierta (1).

González, A. (s.d.). Filosofía de la historia y liberación, ReLat 22.

Hernáez, R. (1999). Filosofía, actualidad e inteligencia en X. Zubiri, The Xavier Zubiri Review, 2.

Maier, M. (1998). La influencia de Karl Rahner en la teología de Ignacio Ellacuría, Revista Latinoamericana de teología, (1996) 39; 44.

Martini, C., Globalización en Solidaridad, artículo ubicable en la siguiente dirección http://www.mensaje.cl/1999/enerofebrerolart2.htm

Ribera, R. (1997). Civilización de la pobreza: la radicalidad del último Ellacuría. Ponencia en el Primer Encuentro Mesoamericano de Filosofía.

Rovaletti, M. (1985). Filosofía y metafísica en X. Zubiri, Revista de filosofía, 18.

Samour, H. (1993). Historia, praxis y liberación en el pensamiento de Ignacio Ellacuría, Ponencia en el primer Congreso Internacional X. Zubiri, Julio.

(1999). La filosofía temprana de Ignacio Ellacuría, en Proceso, 830. (2000). Una filosofía para la vida, ECA 625-626.

(2005). El significado de la filosofía de la liberación hoy, Cuadernos de filosofía latinoamericana, 26: 93.

Valdés, R. (1996). Sobre la evolución del pensamiento filosófico de Ignacio Ellacuría, en ECA n. 577-578.

Sols, J., El pensamiento de Ignacio Ellacuría, Senderos 69 (set-dic 2001). 
